\title{
IS THERE A CO-INTEGRATION BETWEEN EXTERNAL DEBT INTEREST RATE AND GLOBALIZATION? THE CASE OF TURKEY
}

\begin{abstract}
This study explores the long-run association between globalization and external borrowing interest rate. The sample contains a time series data of Turkey containing years from 1970 to 2014. Firstly, a unit root test is conducted to see if the series are stationary or not. Secondly, ARDL bounds test is performed to figure out whether the series move together in the long-run. Then, both shortrun and long-run coefficients of the variables are estimated by employing an error corrected form of ARDL model. Lastly, a causality test is conducted to see if there exists a causality relationship among series. The findings reveal that series of globalization and external borrowing interest rate are co-integrated and thus they move together in the long-run. Estimated long-run coefficients show that globalization has a reducing and statistically significant impact on external borrowing interest rate in Turkey. Moreover, a unidirectional causality running from globalization to external borrowing interest rate is detected. These results also remain valid for two different external borrowing interest rate series, which are interests charged by two different suppliers of official and private creditors.
\end{abstract}

Cüneyt KOYUNCU1 Seyfettin ÜNAL2

Keywords: Globalization, External Debt, ARDL Model, Turkey. Jel Classifications: C32, F15, F65.

\section{ÖZ}

Çalışmada küreselleşme ve dış borç faiz oranı arasındaki uzun dönemli ilişki araştırılmıştır. Kullanılan veri seti Türkiye'ye ilişkin 1970-2014 dönemini kapsayan bir zaman serisidir. Öncelikle, serilerin durağan olup olmadığını belirlemek üzere birim kök testi uygulanmiştır. Daha sonra, serilerin uzun dönemde birlikte hareket edip etmediği sınır testi ile incelenmiștir. Ardından, ARDL modelinin hata düzeltme formu kullanılarak değişkenlerin hem kısa hem de uzun dönem katsayılarının tahminlemesi yapılmıştır. Son olarak, seriler arasındaki nedensellik ilişkisi bulunup bulunmadığı nedensellik testiyle incelenmiştir. Ulaşılan bulgular, küreselleşme ve dış borç faiz oranı serilerinin eş-bütünleşik olduğunu; dolayısıyla, uzun dönemde birlikte hareketini ortaya koymaktadır. Uzun dönemli katsayı tahminlemesi,

\footnotetext{
1 Bilecik Şeyh Edebali Üniversitesi İ̇BF İktisat Bölümü. cuneytkoyuncu@yahoo.com, ORCID: 0000-0002-8638-2761

${ }^{2}$ Kütahya Dumlupınar Üniversitesi İ̉BF İșletme Bölümü. seyfettin.unal@dpu.edu.tr,
} 
küreselleşmenin Türkiye'nin dış borç faiz oranı üzerinde istatistiksel olarak anlamlı olmak üzere düşürücü bir etkisi olduğuna işaret etmektedir. Ayrıca, küreselleşmeden dış borç faiz oranına doğru tek yönlü bir nedenselliğin varlığı tespit edilmiştir. Elde edilen sonuçlar, resmi ve özel kredi verici olmak üzere iki farklı borç sağlayıcının uyguladığı faiz oranları için de geçerliliğini korumaktadır. Türkiye.

Anahtar Kelimeler: Küreselleşme, Dış Borç, ARDL Modeli,

\section{Introduction}

Covering such terms as financial integration and increased international trade, globalization is one broad term. It is the process of a country's complete integration to the rest of the world at almost all institutional levels. Regarding the purpose of this study, Turkey has put much effort into the economics aspects of the subject since the beginning of the 1980s. In order to overcome the weaknesses created by inward-looking import-substitution strategy of the 1970s, outward-looking export-leading development strategy was implemented in the 1980s. This shifting process began with the liberalization of foreign trade regime and capital accounts then became widespread through whole aspects of the economy. One cannot claim that these measures were as smooth with no harmful effects. Furthermore, the globalization has had to come up with its own unique difficulties that economies have to cope with.

With respect to standard neo-classical models, developing countries' external borrowing should be considered favorably. The one of two rationales behind this view is that developing economies may be able to finance their growth by foreign savings since their both capital accumulation and saving rate are low. The other rationale lies behind the consumption smoothing feature of external borrowing based on the anticipation of increase in future income. However, this perspective has undergone a serious questioning during the crises of recent two decades. Therefore, the current account has become the critical driver of changes in external debt. This view expressed in the works by Reisen (1998), Milesi-Ferrett and Razin (1998), Edwards (2001), Calvo (1998) and Kose et al. (2003) yet, has been challenged by a new argument in favor of focusing on gross instead of net flows. This new concept is revealed in works by Johnson (2009), Broner et al. (2011), Borio and Disyatat (2011), Cavallo et al. (2013) and, Bruno and Shin (2013).

54 | Manisa Celal Bayar Üniversitesi Sosyal Bilimler Dergisi - Cilt: 17, Sayı: 2, Haziran 2019 
In addition to conventional indicators, such as trade balances and current accounts, the ongoing course of developing economies' external debt issue needs to be explored with respect to their integration into global financial system. Moreover, Bonizzi et al. (2015) underlines another important aspect of developing countries' external debt. That is, the growth in their external debt is derived from external borrowing undertaken by the private sector. Until the 1990s, the share of public in external borrowing had been weighed high whereas the private sector's share has been gradually increased since the beginning of the 1990s.

Recalling that one of various reasons behind the last global crisis is considered to be the increased indebtedness of all economic units, external borrowing and its cost have become an important issue in recent literature. In this regard, this study investigates the relationship between globalization and external debt interest rate for Turkey. Best to our knowledge, this is the first work touching the subject. The rest of the paper is organized as follows: After the review of related literature, data and methodology section is presented. Following empirical results, the study completes with conclusion section.

\section{Related Literature}

The trend of increasing debt burden on all economic units has become a growing concern for policymakers especially aftermaths of the last global financial crisis. Although different types of borrowing attract researchers' attention for various reasons to examine, this study's focus is on the relationship between the cost of external debt and globalization. Bonizzi et al. (2015) indicate that developing countries' total borrowing has gradually increased, reaching its peak during the last global crisis as a result of quantitative easing efforts in developed economies. On the other hand, interest payments on external debt of developing economies has post a serious drop due to plummeting interest rates.

The association of globalization with various socio-economic factors (e.g., economic growth, corruption and female labor force participation) has been extensively examined in the literature (e.g., Chang et al., 2011; Dreher, 2006; Koyuncu \& Unver, 2017; Cooray et al., 2012; Kucera, 2001; Oksak \& Koyuncu, 2017). Using 44 countries' 200 year-long data set, Reinhart and Rogoff (2010) examine economic growth and inflation at various levels of government and external debt. They report that when external debt reaches $60 \%$ of 
GDP, economic growth drops by $2 \%$. In addition, as countries reach maximum debt tolerance, a pressure on market interest rate to increase arouses hence brings about painful adjustments. Lastly, a higher level of debt to GDP ratio harms emerging countries' growth most.

While similar nonlinear effects of debt on growth are revealed also by Pattillo et al. (2002), Cordella et al. (2010) and, Calvo et al. (2009), Schclarek (2004) finds not enough evidence to support nonlinear relationship between external debt and growth. Among other variables with their association to debt, corruption is also investigated in the literature. Jalles (2011) presents that countries with higher levels of corruption, only the adverse effects of debt on growth are detected.

In the case of Turkey, the evolution of external debt shows similar features. While public's share in external borrowing has been following a decreasing path, the share of private sector has been considerably increasing during the last two decades. Following serious measures taken after the crisis of 2001, capital flow to Turkey has increased dramatically. Furthermore, on the contrary to the previous experience, this new wave of capital flow is realized more in the form of long-term capital which is regarded as the most favored form. Turkey has also benefited from the lower cost of capital due to capital abundancy of the recent global financial crisis. This experience proves the importance of stability in all aspects, including macro economy, financial, political, and legal environment. The stability is supported by improved supervisory, regulatory and institutional quality. Compared to the prior period shaped by shortterm high-cost portfolio inflows mostly used to finance public deficit, FDI-driven long-term low-cost capital inflows has become the start of an entire enhancement.

In part of the related literature, studies have shifted their interest towards microeconomic frictions in financial markets. For example, Gertler and Rogoff (1990) reveal that wealth plays a role as collateral in borrowing, interest rates might be lower in capitalscarce economies than in capital-abundant ones. Taking this insight into account, Boyd and Smith (1997) and, Matsuyama (2004 and 2008) show that financial liberalization may reduce investment and growth in capital-scarce economies.

This view is also supported by the findings of Schularick (2006). According to Schularick's work, total of international capital flows reached $90 \%$ of total global income as of 2001 compared to the 
ratio of $30 \%$ in 1913 . This figure reflects the level of globalization and financial integration. However, developing economies received only $12.5 \%$ of total international capital flow with respect to $48 \%$ in 1913. These studies can be considered to explain the reason behind the flow of capital into wealthy economies. On the other hand, the same fact may also be attributed to the development level of financial markets. Even though the composition of the capital flow is important (e.g., Calvo et al., 1993; Dooley et al., 1997; Calderón and Kubota, 2013), overall the more developed an economy, including especially financial markets, the more it attracts capital. In a growing literature, a number of studies examine this side of the subject. For example, Montiel and Reinhart (2001) regard capital inflow to a developing country as exogenous financial shock. In case this shock is short-term (portfolio investment) for a country with high indebtedness and/or in need of large capital inflow, this inflow is likely to create only a temporal recovery thus referred as risky.

\section{Data and Methodology}

In this study, we examine the causality and long term relationship between globalization and average external debt interest rate. The data are annual and cover the period of 1970-2014 for Turkey. We utilize overall globalization index of KOF globalization index issued by Zurich Technology Institute as an indicator of globalization (GLOBAL). As proxies for external borrowing interest rate, we use two different interest rates. INTEREST1 and INTEREST2 are interest rates charged on external debts obtained from official and private creditors respectively and measured as average of interest rates on new external debt commitments. INTEREST1 and INTEREST2 series are collected from database of WDI.

Due to its advantages mentioned in the literature comparing to conventional co-integration test, we use ARDL boundary test to reveal the potential co-integrating relationship among the series. In order to conduct ARDL boundary test, the following models are estimated:

$$
\begin{aligned}
& \Delta I N T E R E S T 1_{t}=\beta_{0}+\sum_{i=1}^{p} \delta_{i} \text { IINTEREST1 }_{t-i}+\sum_{i=0}^{q} \phi_{i} \Delta G L O B A L_{t-i}+\gamma_{0} \text { INTEREST1 }_{t-1}+\gamma_{1} \text { GLOBAL }_{t-1}+\varepsilon_{t} \\
& \text { SINTEREST2 } 2_{t}=\beta_{0}+\sum_{i=1}^{p} \delta_{i} \text { IINTEREST2 }_{t-i}+\sum_{i=0}^{q} \phi_{i} \Delta \text { GLOBAL }_{t-i}+\gamma_{0} \text { INTEREST2 }_{t-1}+\gamma_{1} \text { GLOBAL }_{t-1}+\varepsilon_{t} \\
& \text { In equations above, } \gamma_{0} \text { and } \gamma_{1} \text { terms stand for long-term }
\end{aligned}
$$


coefficients; $\delta_{i}$ and $\phi_{i}$ terms represent short-term coefficients; $\Delta$ is first degree difference operator; $\beta_{0}$ is constant term of the models, and ${ }^{\varepsilon_{t}}$ is white noise error term of the models.

For the co-integration test, ARDL boundary test approach tests the null hypothesis of $H_{0}: \gamma_{0}=\gamma_{1}=0$ (i.e., there is no cointegrating association among series) against to the alternative hypothesis of $H_{1}: \gamma_{0} \neq \gamma_{1} \neq 0$ (i.e., there exists co-integrating association among series). If the F-statistic value gathered from ARDL boundary test is beyond the upper limit at a particular significance level, then ${ }^{H_{1}}$ hypothesis is accepted. On the other hand, if the F-statistic value is smaller than lower limit at a particular significance level, then $H_{0}$ hypothesis is accepted. Finally, any Fstatistic value falling into the area between the lower and upper limits indicates indecisive zone.

After performing ARDL boundary test, we estimate the following error correction model in order to get both short and longrun coefficients:

$$
\begin{aligned}
& \text { INTEREST }_{t}=\beta_{0}+\sum_{i=1}^{p} \delta_{i} \text { INTEREST }_{t-i}+\sum_{i=0}^{q} \phi_{i} \Delta \text { GLOBAL }_{t-i}+\eta E C M_{t-1}+\varepsilon_{t} \\
& \text { INTEREST2 }_{t}=\beta_{0}+\sum_{i=1}^{p} \delta_{i} \Delta \text { INTEREST }_{t-i}+\sum_{i=0}^{q} \phi_{i} \Delta G L O B A L_{t-i}+\eta E C M_{t-1}+\varepsilon_{t}
\end{aligned}
$$

In equations above, $\delta_{i}$ and $\phi_{i}$ display the dynamic coefficients bringing the model to the balance in the long-run; $E C M$ is error correction term; $\eta$ stands for the speed of adjustment at which the model reverts to long-run balance after a shock occurred in short run. The speed of adjustment term is expected to be negative and statistically significant.

Lastly, we check if there is a causality relationship between the series by utilizing VAR Granger Causality/Block Exogeneity Wald Test in the framework of Toda-Yamamoto method. In the first step of Toda-Yamamoto method, we need to identify maximum integration level of series. In the second step, we determine optimal lag length of unrestricted VAR model based upon model selection criteria. In the third step, given that maximum integration level of series is " $d$ " and 
optimal lag length is " $p$ ", an unrestricted VAR model with $p+d$ lags model is estimated. This estimated model is used to conduct VAR Granger Causality/Block Exogeneity Wald Test in order to reveal causality relationship.

\section{Empirical Results}

We use Phillips-Perron (PP) stationarity test to see if the series are stationary or not. The null hypothesis of the PP test asserts non-stationarity of series whereas the alternative one claims stationary of series. Table 1 displays the results of PP unit root tests.

Table 1: Unit Root Test Results

\begin{tabular}{|c|c|c|}
\hline Variable & Model & Test Statistic (P-value) \\
\hline \multirow{2}{*}{ GLOBAL } & $\begin{array}{l}\text { None } \\
\text { Constant }\end{array}$ & $\begin{array}{l}3.211144(0.9995) \\
-0.369836(0.9054)\end{array}$ \\
\hline & Constant, Linear Tr. & $-1.960445(0.6061)$ \\
\hline \multirow{2}{*}{$\Delta \mathrm{GLOBAL}$} & $\begin{array}{l}\text { None } \\
\text { Constant }\end{array}$ & $\begin{array}{l}-5.443697(0.0000) \\
-6.587850(0.0000)\end{array}$ \\
\hline & Constant, Linear Tr. & $-6.508527(0.0000)$ \\
\hline \multirow[t]{2}{*}{ INTEREST1 } & $\begin{array}{l}\text { None } \\
\text { Constant }\end{array}$ & $\begin{array}{l}-0.704891(0.4057) \\
-1.279674(0.6307)\end{array}$ \\
\hline & Constant, Linear Tr. & $-2.753809(0.2214)$ \\
\hline \multirow{2}{*}{$\Delta$ INTEREST1 } & $\begin{array}{l}\text { None } \\
\text { Constant }\end{array}$ & $\begin{array}{l}-8.097942(0.0000) \\
-8.024132(0.0000)\end{array}$ \\
\hline & Constant, Linear Tr. & $-8.954501(0.0000)$ \\
\hline \multirow[t]{2}{*}{ INTEREST2 } & $\begin{array}{l}\text { None } \\
\text { Constant }\end{array}$ & $\begin{array}{l}-0.640243(0.4342) \\
-2.537165(0.1139)\end{array}$ \\
\hline & Constant, Linear Tr. & $-3.705838(0.0324)$ \\
\hline \multirow[t]{2}{*}{$\Delta$ INTEREST2 } & $\begin{array}{l}\text { None } \\
\text { Constant }\end{array}$ & $\begin{array}{l}-9.164773(0.0000) \\
-9.081319(0.0000)\end{array}$ \\
\hline & Constant, Linear Tr. & $-10.12742(0.0000)$ \\
\hline
\end{tabular}

If we evaluate the test results at $1 \%$ significance level, we see that GLOBAL, INTEREST1, and INTEREST2 variables are not stationary at level but they are stationary at first differences (i.e., integrated order one I(1)). Since ARDL boundary test allows series to be integrated at any order rather than integration order two or more, we can use ARDL boundary test approach to check the co-integration relationship among our series. 
In the next step, we utilize the Schwarz criterion to identify the optimal leg lengths of our models. Figure 1 and 2 below depicts the top twenty results for our two models given in equation 1 and 2 respectively. As a result of the evaluation of 156 different models based on Schwarz selection criterion, the best model is ARDL $(3,7)$ for the model in equation 1 and ARDL $(1,0)$ for the model in equation 2 .

Schwarz Criteria (top 20 models)

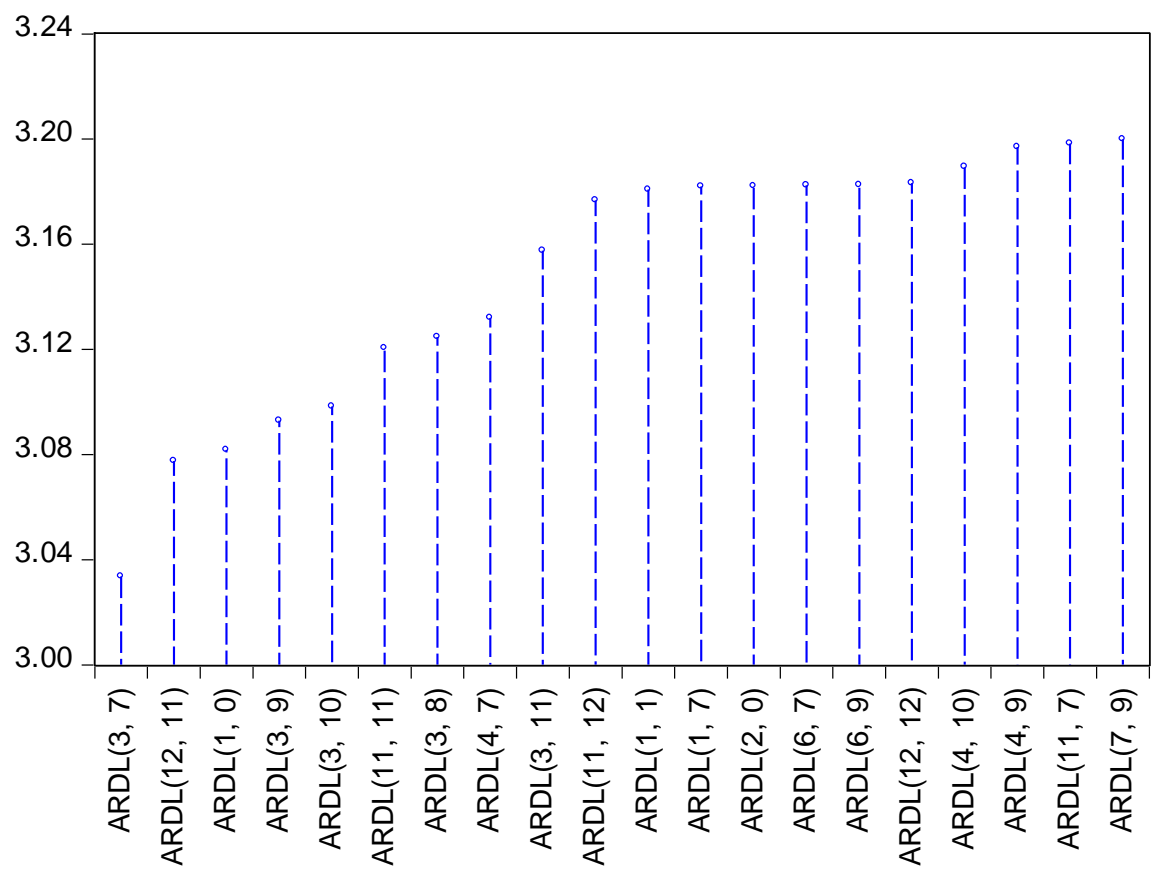

Figure 1: Optimal Lag Length Selection for the Model in Equation 1 
Schwarz Criteria (top 20 models)

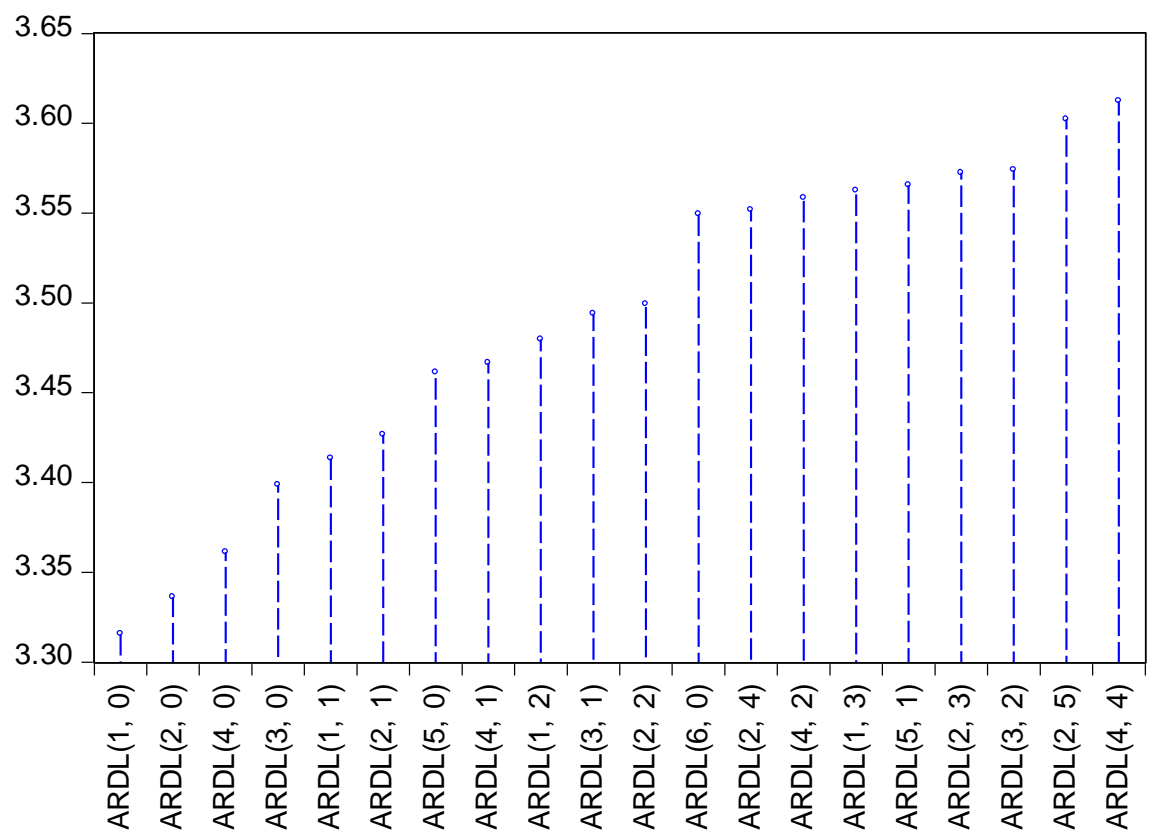

Figure 2: Optimal Lag Length Selection for the Model in Equation 2

The co-integration test results gathered from ARDL bound tests are reported in Table 2 and 3 for the models in equation 1 and 2. F-statistic value in Table 2 is greater than upper bound critical values (i.e., values at I(1) Bound column) at all significance levels and F-statistic value in Table 3 is greater than upper bound critical values at all significance levels except for $1 \%$ significance level. Once we assess the findings in Table 2 and 3 at $5 \%$ significance level, we conclude that there exists a long-run association among the series. In other words, GLOBAL variable is co-integrated with both INTEREST1 and INTEREST2 variables.

Table 2: ARDL Bounds Test Estimation Results for the Model in Equation 1

\begin{tabular}{|c|c|c|}
\hline $\begin{array}{r}\text { F-statistic } \\
8.884238\end{array}$ & \multicolumn{2}{|c|}{ Critical Values } \\
\hline Significance & und ${ }^{I(0)}$ Bo & ${ }^{I(1)} \mathrm{Bou}$ \\
\hline $10 \%$ & 4.04 & 4.78 \\
\hline
\end{tabular}


Cüneyt KOYUNCU-Seyfettin ÜNAL

\begin{tabular}{|l|l|l|}
\hline $5 \%$ & 4.94 & 5.73 \\
\hline $2.5 \%$ & 5.77 & 6.68 \\
\hline $1 \%$ & 6.84 & 7.84 \\
\hline
\end{tabular}

Table 3: ARDL Bounds Test Estimation Results for the Model in Equation 2

\begin{tabular}{|c|c|c|}
\hline $\begin{array}{l}\text { F-statistic } \\
7.328290\end{array}$ & \multicolumn{2}{|c|}{ Critical Values } \\
\hline Significance & und ${ }^{I(0)}$ Bo & ${ }^{I(1)} \mathrm{Bou}$ \\
\hline $10 \%$ & 4.04 & 4.78 \\
\hline $5 \%$ & 4.94 & 5.73 \\
\hline $2.5 \%$ & 5.77 & 6.68 \\
\hline $1 \%$ & 6.84 & 7.84 \\
\hline
\end{tabular}

Long-run coefficient estimation results in Table 4 hint that there is a negative and statistically significant association between GLOBAL variable and INTEREST1 and INTEREST2 variables. These findings confirm the co-integration test results in Table 2 and 3. Thus, we can say that as globalization increases, the average interest rate charged on external loans by both official and private creditors decreases in the long-run for Turkey.

Table 4: Long-run Coefficients of ARDL $(3,7)$ and ARDL $(1,0)$ Models

\section{Dependent Variable: INTEREST1}

\begin{tabular}{|l|l|l|l|}
\hline Variable & Coefficient & t-statistic & Prob. \\
\hline GLOBAL & -0.133411 & -7.898553 & 0.0000 \\
\hline Dependent Variable: INTEREST2 \\
\hline Variable & Coefficient & t-statistic & Prob. \\
\hline GLOBAL & -0.112292 & -3.204447 & 0.0026 \\
\hline
\end{tabular}

From Table 5, we see that only third and sixth period's shortrun coefficients of GLOBAL variable in $\operatorname{ARDL}(3,7)$ model are statistically significant and have a positive sign. Also, the ECM coefficient receives the anticipated negative sign and is statistically

62 | Manisa Celal Bayar Üniversitesi Sosyal Bilimler Dergisi - Cilt: 17, Sayi: 2, Haziran 2019 
significant at 1\% significance level. According to the diagnostic tests, there exists no problem in $\operatorname{ARDL}(3,7)$ model in terms of autocorrelation, heteroscedasticity, normality, and model specification error at $1 \%$ significance level.

Table 5: Error Correction Estimation (ECM) Results of ARDL $(3,7)$ Model

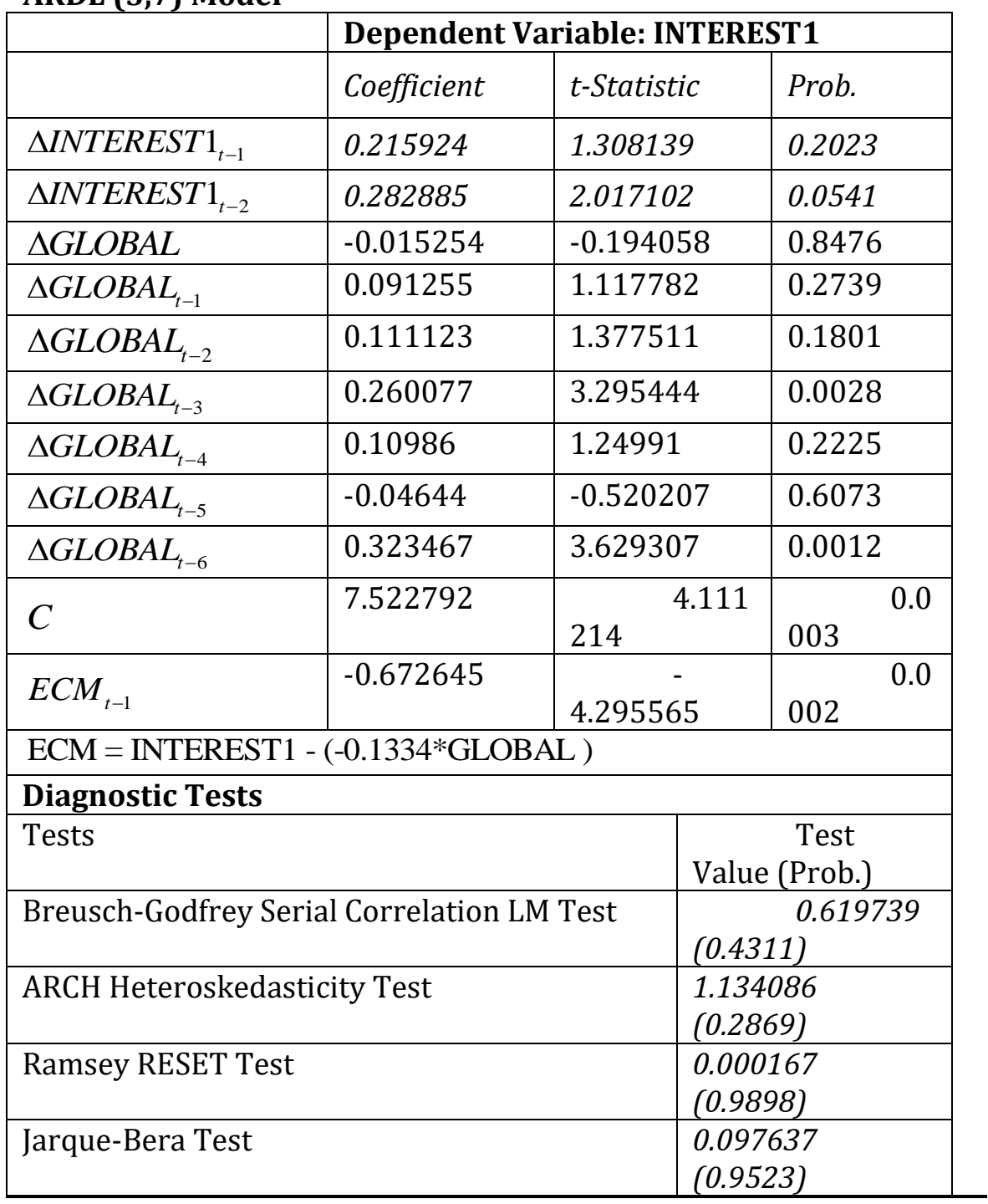


It can be seen from Table 6 that the ECM coefficient receives the anticipated negative sign and is statistically significant at $1 \%$ significance level. According to diagnostic tests, there is no a problem in ARDL $(1,0)$ model in terms of autocorrelation, heteroscedasticity, and model specification error at $1 \%$ significance level.

Comparing the speed of adjustment terms of ARDL $(3,7)$ and ARDL $(1,0)$ models, adjustment speed of $\operatorname{ARDL}(3,7)$ model is higher than ARDL $(1,0)$ model.

Table 6: Error Correction Estimation (ECM) Results of ARDL $(1,0)$ Model

\begin{tabular}{|l|l|l|l|}
\hline & Dependent Variable: INTEREST2 \\
\hline & Coefficient & t-Statistic & Prob. \\
\hline$\Delta G L O B A L$ & -0.068802 & -0.487129 & 0.6288 \\
\hline$C$ & 6.401209 & 3.817423 & 0.0004 \\
\hline$E C M_{t-1}$ & -0.468434 & -3.864832 & 0.0004 \\
\hline ECM = INTEREST2 -(-0.1123*GLOBAL ) \\
\hline Diagnostic Tests & Test Value (Prob.) \\
\hline Tests & $0.442692(0.5058)$ \\
\hline Breusch-Godfrey Serial Correlation LM Test & $2.862873(0.0906)$ \\
\hline ARCH Heteroskedasticity Test & $0.719892(0.4012)$ \\
\hline Ramsey RESET Test & $9.706998(0.0078)$ \\
\hline Jarque-Bera Test
\end{tabular}

In the last part of the study, we conduct a Granger causality test in the framework of Toda Yamamoto approach to find out whether or not there is a causality relationship among the series. The maximum integration level for the series is 1 since all series are stationary at first differences.

For unrestricted VAR model constructed by using GLOBAL and INTEREST1 series, we get Schwarz criterion=7.147610 value for one lag model and Schwarz criterion=7.442913 value for two lag model. As Schwarz criterion value is lower for one lag model, the optimal lag length is one. Finally, we estimate VAR(2) model by using GLOBAL and INTEREST1 series to get Granger Causality/Block Exogeneity Wald Test results.

Since Schwarz criterion=8.059172 value for one lag and Schwarz criterion $=8.397526$ value for two lag models are gathered for VAR model constructed by using GLOBAL and INTEREST2

64 | Manisa Celal Bayar Üniversitesi Sosyal Bilimler Dergisi - Cilt: 17, Sayı: 2, Haziran 2019 
variables, the optimal lag length is one. Finally, we estimate VAR(2) model by using GLOBAL and INTEREST2 series to get Granger Causality/Block Exogeneity Wald Test results.

Causality test findings are displayed in Table 7 below. A unidirectional causality is detected running from GLOBAL to INTEREST1 and INTEREST2.

Table 7: Causality Test Results

\begin{tabular}{|c|c|c|c|}
\hline \multicolumn{5}{|c|}{ Dependent Variable: INTEREST1 } \\
\hline Excluded & Chi-sq & $d f$ & Prob. \\
\hline GLOBAL & 8.765940 & 2 & 0.0125 \\
\hline \multicolumn{4}{|c|}{ Dependent Variable: GLOBAL } \\
\hline Excluded & Chi-sq. & $d f$ & Prob. \\
\hline INTEREST1 & 2.183173 & 2 & 0.3357 \\
\hline \multicolumn{5}{|c|}{ Dependent Variable: INTEREST2 } \\
\hline Excluded & Chi-sq & $d f$ & Prob. \\
\hline GLOBAL & 7.640951 & 2 & 0.0219 \\
\hline \multicolumn{5}{|c|}{ Dependent Variable: GLOBAL } \\
\hline Excluded & Chi-sq & $d f$ & Prob. \\
\hline INTEREST2 & 0.830809 & 2 & 0.6601 \\
\hline
\end{tabular}

\section{Conclusion}

Especially aftermaths of the recent global financial crisis, the trend of increasing debt burden on all economic units has created a growing concern for policymakers and hence urged them to take steps towards controlling the matter. As the degree of globalization of a country in the sense of economic, political, and social globalization increases, the relevant country adopts universal rules and norms, becomes a part of well-known economic and politic institutions and organizations. Consequently, country's risk premium is expected to decline hence country may be able to find external loans at lower interest rates. Based on this intuition, this study aims to investigate long-run relationship between globalization and external borrowing interest rate for Turkey and is expected to have a negative association between the relevant series. The sample contains time series data for Turkey covering the years from 19702014. Moreover, the causality relationship among series is examined as well. 
According to ARDL bound test results, there is a long-run association between globalization and external borrowing interest rate, and thus the series are co-integrated. A positive statistically significant longrun coefficient is gathered for globalization variable and therefore we can conclude that globalization has a reducing impact on external borrowing interest rate for Turkey in the long-run. Causality test findings indicate that there is a unidirectional causality relationship running from globalization to external borrowing interest rate.

\section{References}

BONIZZI, Bruno, Christina LASKARIDIS \& Jan TOPOROWSKI (2015), “Developing Countries' External Debt and International Financial Integration", Financialisation, Economy, Society and Sustainable Development Working Paper Series, 121.

BORIO, C. and P. DISYATAT (2011), "Global Imbalances and the Financial Crisis: Link or No Link?", BIS Working Paper, Bank for International Settlements.

BOYD, John H., and Bruce D. SMITH (1997), "Capital Market Imperfections, International Credit Markets, and Nonconvergence," Journal of Economic Theory, 73, 335-364.

BRONER, F., T. DIDIER, A. ERCE and S.L. SCHMUKLER (2011), “Gross Capital Flows: Dynamics and Crises”, Policy Research Working Paper Series, The World Bank.

BRUNO, V. and H.S. Shin (2013), "Capital Flows, Cross-Border Banking and Global Liquidity", National Bureau of Economic Research, Working Paper.

CALDERÓN, C. \& M. KUBOTA (2013), "Sudden stops: Are global and local investors alike?" Journal of International Economics, $89,122-142$.

CALVO, G.A. (1998) "Capital Flows and Capital-Market Crises: The Simple Economics of Sudden Stops", Journal of Applied Economics, 1, 35-54.

CALVO, G.A., L. LEIDERMAN \& C.M. REINHART (1993), "Capital inflows to Latin America: The role of external factors", International Monetary Fund Staff Papers, 40, 108-151.

CALVO, D.R., J.H. STEFANOUDAKIS \& J.M. BLANCO TAMES (2009), "External Debt and Economic Growth", Malardalen University. Retrieved October 26, 2015, from http://mdh.divaportal.org/smash/ get/diva2:236410/FULLTEXT01.pdf.

CAVALLO, E.A., A. POWELL, M. PEDEMONTE and P. TAVELLA (2013), “A New Taxonomy of Sudden Stops: Which Sudden Stops

66 | Manisa Celal Bayar Üniversitesi Sosyal Bilimler Dergisi - Cilt: 17, Sayı: 2, Haziran 2019 
Should Countries Be Most Concerned About?", Research Department Publications, Inter-American Development Bank.

CHANG, C.P., C.C. LEE, M.C. HSIEH (2011), "Globalization, Real Output and Multiple Structural Breaks", Global Economic Review, $40(4), 421-444$.

COORAY, A., I. GADDIS \& K.M. WACKER (2012), “Globalization and female labor force participation in developing countries: An empirical (re-)assessment, Courant Research Centre: Poverty", Equity and Growth-Discussion Papers, No. 129.

CORDELLA, T., L.A. RICCI \& M. RUIZ ARRANZ (2010), “Debt Overhang or Debt Irrelevance?”, IMF Staff Papers, 57(1), 1-24. doi:10.1057/imfsp.2009.20.

DOOLEY, M., E. FERNANDEZ-ARIAS \& I. SHIN (1997), “Private inflows when crises are anticipated: A case study of Korea”, Unpublished manuscript.

DREHER, A. (2006), "Does Globalization Affect Growth? Evidence from A New Index of Globalization", Applied Economics, 38(10), 1091-1110.

EDWARDS, S. (2001), "Does the Current Account Matter?", Working Paper, National Bureau of Economic Research.

GERTLER, Mark and Kenneth ROGOFF (1990), "North-South Lending and Endogenous Domestic Capital Market Inefficiencies", Journal of Monetary Economics, 26, 245-266.

JALLES, J.T. (2011), "The Impact of Democracy and Corruption on the Debt-Growth Relationship in Developing Countries", Journal of Economic Development, 36(4), 41-72.

JOHNSON, K.H. (2009), "Gross or Net International Financial Flows: Understanding the Financial Crisis", CGS Working Paper, Council on Foreign Relations.

KOSE, M.A., E.S. PRASAD and M.E. TERRONES (2003), "Financial Integration and Macroeconomic Volatility", IMF Staff Papers, 50, 119-142.

KOYUNCU, Julide Yalcinkaya and Mustafa UNVER (2017), "The Association between Corruption and Globalization in African Countries", Social Sciences Research Journal, Volume 6, Issue 4, pp.20-28.

KUCERA, D. (2001), "Foreign Trade of manufactures and men and women's employment and earnings in Germany and Japan", International Review of Applied Economics, 15(2), 130-148. doi. 10.1080/02692170151136998. 
MATSUYAMA, Kiminori (2004), "Financial Market Globalization, Symmetry-Breaking and Endogenous Inequality of Nations", Econometrica, 72, 853-884.

MATSUYAMA, Kiminori (2008), "Aggregate Implications of Credit Market Imperfections", NBER Macroeconomics Annual, 2007, 22, 1-60.

MILESI-FERRETT, G.M. and A. RAZIN, A. (1998), "Current Account Reversals and Currency Crises: Empirical Regularities", Working Paper, National Bureau of Economic Research.

PATTILLI, C., H. POIRSON \& L. RICCI (2002), "External Debt and Growth". Finance \& Development, 39(2), 32-35.

MONTIEL, P. \& M.C. REINHART (2001), "The dynamics of capital movements to emerging economies during the 1990s", UNU/WIDER Project on Short-term Capital Movements and Balance of Payments Crises.

OKSAK, Yuksel and Julide Yalcinkaya KOYUNCU (2017), “Does Globalization Affect Female Labor Force Participation: Panel Evidence", Journal of Economics Bibliography, Volume 4, Issue 4, pp.381-387.

REINHART, C.M. \& K.S. ROGOFF (2010), "Growth in a Time of Debt". The American Economic Review, 100(2), 573-578. doi:10.1257/aer.100.2.573.

REISEN, H. (1998), "Sustainable and Excessive Current Account Deficits", OECD Development Centre Working Paper, OECD Publishing.

SCHCLAREK, A. (2004), "Debt and Economic Growth in Developing and Industrial Countries", Lund: Lund University, Retrieved October 26, 2015, from https://lup.lub.lu.se/luur/download?func=downloadFile\&recordOId $=1387405$ \&fileOId $=2061440$.

SCHULARICK, M. (2006), "A tale of 'Two Globalizations': Capital flows from rich to poor in eras of global finance", International Journal of Finance and Economics, 11, 339-354. 